Biuletyn Historii Sztuki

LXXXII:2020, nr 1

ISSN 00063967

MACIEJ JARZEWICZ

Warszawa, Instytut Sztuki PAN

https://orcid.org/0000-0003-2047-3625

\title{
Idealizacja w karykaturze. \\ Karykatura jako idealizacja - szkic zagadnienia
}

Idealization in Caricature.

Caricature as Idealization. A Sketch 
Termin „idealizacja” ma dwa znaczenia. Stosowane zazwyczaj w refleksji o sztuce to upodobnienie przedmiotu do przyjętego wzorca piękna, czyli w sprzeczności z karykaturą. Idealizacja w filozofii nauki polega na uwzględnieniu jedynie istotnego aspektu badanego przedmiotu. Artykuł jest poświęcony konsekwencjom uznania idealizacji za istotną cechę karykatury, porównywalną z rolą idealizacji w nauce.

Słowa klucze: karykatura, idealizacja, filozofia nauki, Leszek Nowak, Gianlorenzo Bernini

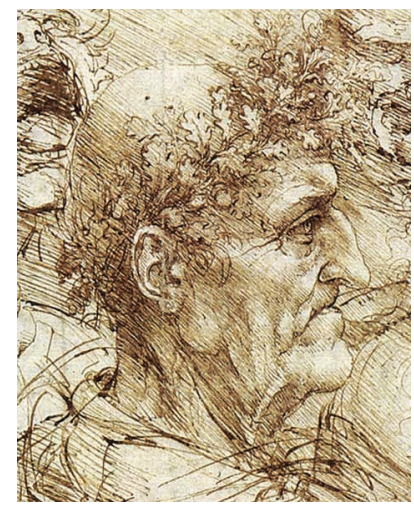

The term 'idealization' has two meanings. Applied most commonly in reflection on art, it means making an object resemble the assumed model of beauty, just contrariwise to caricature. Idealization in science philosophy consists in taking into account merely one key aspect of the investigated object. The paper deals with the consequences of assuming idealization to be an essential feature of caricature, comparable to idealization in science.

Key words: caricature, idealization, philosophy of science, Leszek Nowak, Gianlorenzo Bernini 
$\mathrm{W}$ pierwszej chwili mało co wydaje się dalsze niż karykatura i idealizacja. Zamierzam, przynajmniej początkowo, potraktować te kategorie ahistorycznie, uznając ich ważkość w formach używanych powszechnie w historii sztuki i pokrewnych dyscyplinach. Można mieć wątpliwości dotyczące sensu używania słowa „karykatura” w odniesieniu do zjawisk artystycznych wcześniejszych niż wprowadzenie tego terminu na początku XVII w. Najczęściej przyjmuje się za zasadne mówienie o karykaturze od czasów Leonarda i jego studiów fizjonomicznych zwanych także ,groteskowymi głowami”. Argumentem za takim rozstrzygnięciem jest istnienie powszechnie uznanego kanonu piękna i właściwego przedstawiania, co zdaniem Wernera Hofmanna jest warunkiem koniecznym dla zaistnienia karykatury ${ }^{1}$.

Podobieństwo karykatury i idealizacji w sztuce wysokiej zostało zauważone na samym początku funkcjonowania pierwszego z wymienionych pojęć w słowie pisanym. Giovanni Antonio Massani porównywał we wstępie do zbioru rycin według rysunków Annibale Carracciego postępowanie karykaturzysty do idealizującego malarza, posługując się przykładem Rafaela. Według Massaniego, klasycyzujący artysta, niezadowolony z niedostatecznego piękna rzeczywistej natury udoskonala ją, a tworzący karykaturę również udoskonala niedostatecznie brzydkie pierwowzory, dążąc do piękna deformacji (bellezza della deformità $)^{2}$. Odejście od realności zostało wcześnie zauważone zarówno w odniesieniu do sztuki idealizującej, jak i karykatury, ale mimo to mamy do czynienia z wyraźnie rozgraniczoną sztuką wysoką i satyrą wizualną.

Czym jest więc „karykatura” w powszechnym pojmowaniu? Polski historyk sztuki dysponuje krótką definicją ,karykatury” ze Słownika terminologicznego sztuk pięknych: ,,przesadne, ośmieszające uwypuklenie i wyolbrzymienie charakterystycznych cech postaci, przedmiotów, grup społ. lub wydarzeń (k. portretowa, obyczajowa, polit. okolicznościowa).

\footnotetext{
${ }^{1}$ Werner Hofmann, Die Karikatur von Leonardo bis Picasso, (Wien: Philo Fine Arts, 1956), s. 16. Z tym stanowiskiem można polemizować uznając pewne starożytne i średniowieczne przykłady za odpowiadające definicji karykatury, a samo zjawisko za ponadczasowe. Z drugiej strony historię karykatury można rozpoczynać dopiero od przełomu XVI i XVII w., w momencie pojawienia się tego pojęcia.

${ }^{2}$ Giovanni Atanasio Mosini [właśc. Giovanni Antonio MASSANI], „A tutti coloro. Che della professione ingegnofissima del Disegno si dilettanto", w: Diverse figure al numero di ottanta, disegnate di penna, nell'hore di ricreatione da Annibale Carracci Intagliate in rame, e cavate dagli originali da Simone Guilino Parigino. Per utile di tutti li virtuosi, et intendenti, della professione della pittura, e del disegno [Le Arti di Bologna], (Roma: Nella Stamperia di Lodovico Grigniani, 1646), s. 16. Jak zauważyła Sheila McTighe, ryciny zawarte w przywoływanym tomie nie spełniają współczesnych (i zapewne ówczesnych) kryteriów karykatury, choć inne rysunki Carraccich miały taki charakter, jak również obrazki z Le Arti di Bologna zainspirowały innych artystów do stworzenia ewidentnych karykatur; zob. Sheila McTigHE, „Perfect Deformity, Ideal Beauty, and the «Imaginaire» of Work: The Reception of Annibale Carracci's «Arti di Bologna» in 1646”, Oxford Art Journal 16, nr 1 (1993), s. 85-87. O koncepcji ,perfekcyjnej deformacji” w nowożytnych Włoszech dowiedziałem się z referatu Katarzyny Murawskiej-Muthesius „Perfetta deformita i ucieleśniony podmiot: 0 nowożytnej teorii karykatury” wygłoszonego na konferencji „Ciało w karykaturze, karykatura ciała w sztuce” organizowanej przez Instytut Sztuki PAN i Muzeum Karykatury w Warszawie 24 X 2018. Pierwotna wersja niniejszego tekstu była zaprezentowana na tym samym sympozjum.
} 
W sztukach plastycznych właściwe k. wyraziły się w rysunku i grafice"’3. Dalej hasło słownikowe omawia historię wskazując na istnienie elementów karykatury w sztuce starożytnej i średniowiecznej, jednak uznaje za kluczowy moment rozwoju portretowe karykatury Leonarda.

W cytowanym słowniku nie ma jednak haseł takich jak ,idealizacja” i ,realizm”, co jest zgodne $\mathrm{z}$ akcentowaniem technicznych aspektów sztuk plastycznych przy pominięciu zagadnień ogólniejszych związanych z retoryką, estetyką czy zjawiskami o charakterze ogólnokulturowym. Aby uzyskać proste definicje odpowiadające powszechnie stosowanemu uzusowi, trzeba się zwrócić do Słownika terminów literackich, w którym, zgodnie z deklaracją autorów, uwzględniono terminy nie tylko swoiste dla badań literackich, ale też pokrewnych dziedzin. Są więc w jednym słowniku noty poświęcone „karykaturze” i ,idealizacji”. Zgodnie z hasłem autorstwa Janusza Sławińskiego: „Karykatura [...] sposób przedstawienia postaci literackiej polegający na wyolbrzymieniu i pełnym przesady wyjaskrawieniu pewnych cech jej wyglądu zewnętrznego lub postawy wobec życia, mający na celu ośmieszającą charakterystykę. K. jest jednym z uprzywilejowanych instrumentów satyry"4.

Nietrudno domyślić się, że ,idealizacja” ma przeciwstawne znaczenie. Według Teresy Kostkiewiczowej jest to ,stosowany w sztuce i literaturze sposób przedstawiania rzeczywistości według określonego wzorca (np. estetycznego, moralnego itp.) uznanego za doniosły (idealny). Postulat i. pojawił się w estetyce antycznej, m.in. w znanej formule Arystotelesa mówiącej, że dzieło lit. winno przedstawiać ludzi nie takich, jakimi są, lecz takich, jakimi być powinni. Za antykiem kategorię i. przejęło średniowiecze. Odegrała ona także znaczną rolę w schyłkowych i bliskich rokoku nurtach klasycyzmu, zalecających imitację pięknej natury. I. jako kategoria moralna właściwa jest wszelkim odmianom dydaktycznej literatury. Por. piękno, wzniosłość" 5 .

Obok ,idealizacji” w Stowniku terminów literackich zamieszczono hasło „idea”, którego definicja pokazuje jak bardzo oddaliły się od siebie dwa pojęcia o wspólnym słoworodzie: „Idea [...] centralny element zawartości ideowej utworu, jego myśl przewodnia, główna prawda (metafizyczna, psychologiczna, polityczna itp.), której utwór dowodzi, lub za którą się opowiada. I. sprzęga wewnętrznie materiał ideologiczny dzieła i jest najbardziej ogólną formułą postawy autora wobec tej sfery rzeczywistości pozaliterackiej, do której dzieło nawiązuje poprzez swój świat przedstawiony. Może występować w dwojakiej postaci: jako problem, bądź jako tendencja”6. „Idea” według tej definicji jest główną osią dzieła, podstawowym przekazem, który odnosi się do rzeczywistości pozaliterackiej. W tym kontekście nie jest ważne, czy chodzi o ideał, do którego należy dążyć, czy wręcz przeciwnie; ,idea" może też odnosić się do spraw, które autor/narrator postrzega z mieszanymi uczuciami. W świetle omawianych definicji, mimo tej samej etymologii, ,idealizacja” ma ograniczone powiązanie z ,ideą", „idealizacja” może być jedynie środkiem ułatwiającym przekazanie odbiorcom pożądanej przez autora tendencji.

„Idealizacja” jest też istotnym pojęciem w filozofii nauk przyrodniczych. Przejście pomiędzy znaczeniem tego samego słowa w różnych dziedzinach wiedzy może wydawać się nieuprawnione, ponieważ jego użycie bywa czysto metaforyczne. Przykładem niech bę-

\footnotetext{
3 „Karykatura”, w: Słownik terminologiczny sztuk pięknych, red. Stefan KozAKIEwICz (Warszawa: PWN, 1969), s. 165.

${ }^{4}$ Janusz SŁAwIŃski, „Karykatura”, w: Słownik terminów literackich, red. Janusz SŁAwIŃsKi (Wrocław: Zakład Narodowy im. Ossolińskich, 1998), s. 215.

${ }^{5}$ Teresa KostKiewiczowa, „Idealizacja”, w: Stownik terminów, s. 190.

${ }^{6}$ Janusz SŁAwIŃSKI, „Idea”, w: Słownik terminów, s. 190.
} 
dzie głębia oceanu i głębia w psychologii - zapewne głębia w psychologii niewiele powie oceanografom badającym morza. Jestem jednak przekonany, że w tym przypadku tak nie jest.

Jednym z ważniejszych propozycji badawczych w filozofii jest idealizacyjna teoria nauki Leszka Nowaka, uczonego rozpoczynającego swoją drogę od marksizmu zestawianego z pozytywizmem logicznym, później zaś szerzej znanego z krytycznego ujęcia marksowskiej filozofii społecznej oraz ogólnej teorii władzy. Idealizacja w ujęciu Nowaka nie jest postulowanym sposobem działalności naukowej, tylko niezbędnym elementem rzeczywistej procedury. Rozpoczyna on Wstęp do idealizacyjnej teorii nauki od opisania badań nad spadkiem swobodnym ciał prowadzonymi przez Galileusza i Newtona, które doprowadziły do odkrycia praw grawitacji ${ }^{7}$. Zgodnie z rekonstrukcją postępowania badawczego dokonaną przez Nowaka najpierw należy odrzucić wszelkie nieistotne czynniki, jak na przykład opór powietrza i skupić się na właściwych, istotnych zależnościach. Następnie trzeba formułować prawo dotyczące tej najważniejszej kwestii, a na trzecim etapie powracać do empirii w procesie konkretyzacji, kiedy uwzględnia się pominięte wcześniej czynniki. W przeciwieństwie do falsyfikacyjnej teorii Poppera, sprawdzeniu podlegałyby nie prawa przyrody tylko ich konkretyzacje. Dzięki temu można by wyjaśnić, dlaczego spadająca kartka papieru nie porusza się zgodnie z przewidywaniami Newtona, a jednak prawa grawitacji są zasadniczo słuszne. Nowak konfrontuje nowoczesne postępowanie naukowe (Galileusz, Newton) o idealizacyjnym charakterze z empiryczno-rozsądkowym postępowaniem Arystotelesa. Aby unaocznić różnice w tym podejściu, pisze, że na pytanie: jak poruszałyby się ciała, gdyby nie było oporów ośrodka, Arystoteles odpowiedziałby, że próżnia nie istnieje, więc nie ma sensu rozważać takiej sytuacji ${ }^{8}$.

Wyżej opisana praktyka naukowa często pozostawała w sprzeczności z deklarowanymi przez samych uczonych przekonaniami. Świadomość metodologiczna społeczności naukowej nie jest istotna w teorii Nowaka, podobnie jak dziedzina wiedzy. We Wstęie do idealizacyjnej teorii nauki pojawiają się przykłady z mechaniki gazów i ekonomii (marksowskiej), pojawia się też uogólniony opis praktyki badawczej: „W konsekwencji wiedza naukowa (w odróżnieniu od zdrowego rozsądku kontentującego się opisem faktów) zmierza do uchwycenia tego, co w faktach jest istotne, aby na tej podstawie zrozumieć zasady ich występowania. Środkiem podstawowym, jakim nauka się posługuje jest abstrakcja (idealizacja), polegająca na pominięciu zjawiskowego aspektu badanych zdarzeń. Przyjmuje się więc, że czynniki uboczne nie działają, a jedynymi determinantami badanych wielkości są czynniki dla nich główne. Ustala się w ten sposób zasadnicze prawa podające jak zależą wielkości badane od czynników głównych a zarazem abstrahujące od wszelkich czynników wtórnych. Określiwszy zatem istotę badanych faktów uwzględnia się następnie ich aspekt zjawiskowy - prawa te są konkretyzowane. Bierze się, mianowicie, pod uwagę kolejne czynniki uboczne pokazujące zarazem, jakie poprawki należy w związku z tym wprowadzić do wyjściowych praw. W ten sposób, w rezultacie uchwycenia istotnościowego aspektu faktów, jak i uwzględnienia ich aspektu zjawiskowego, fakty zostają wyjaśnione"9.

Idealizacja jako oderwanie, a przynajmniej wzięcie w nawias nieistotnych cech, aby dotrzeć do zasadniczej istoty rozpatrywanego zjawiska, występuje również w karykatu-

\footnotetext{
${ }^{7}$ Leszek NowaK, Wstep do idealizacyjnej teorii nauki (Warszawa: PWN, 1977), s. 7-17.

${ }^{8}$ Odpowiedź na pytanie, czy Nowak (ibid., s. 12) nie uprościł nadmiernie (Arystoteles rozróżniał przypadłościowy i istotny aspekt rzeczy), nie należy do zadań, które stawiam sobie pisząc ten artykuł.

${ }^{9}$ NowaK, Wstęp, s. 21.
} 


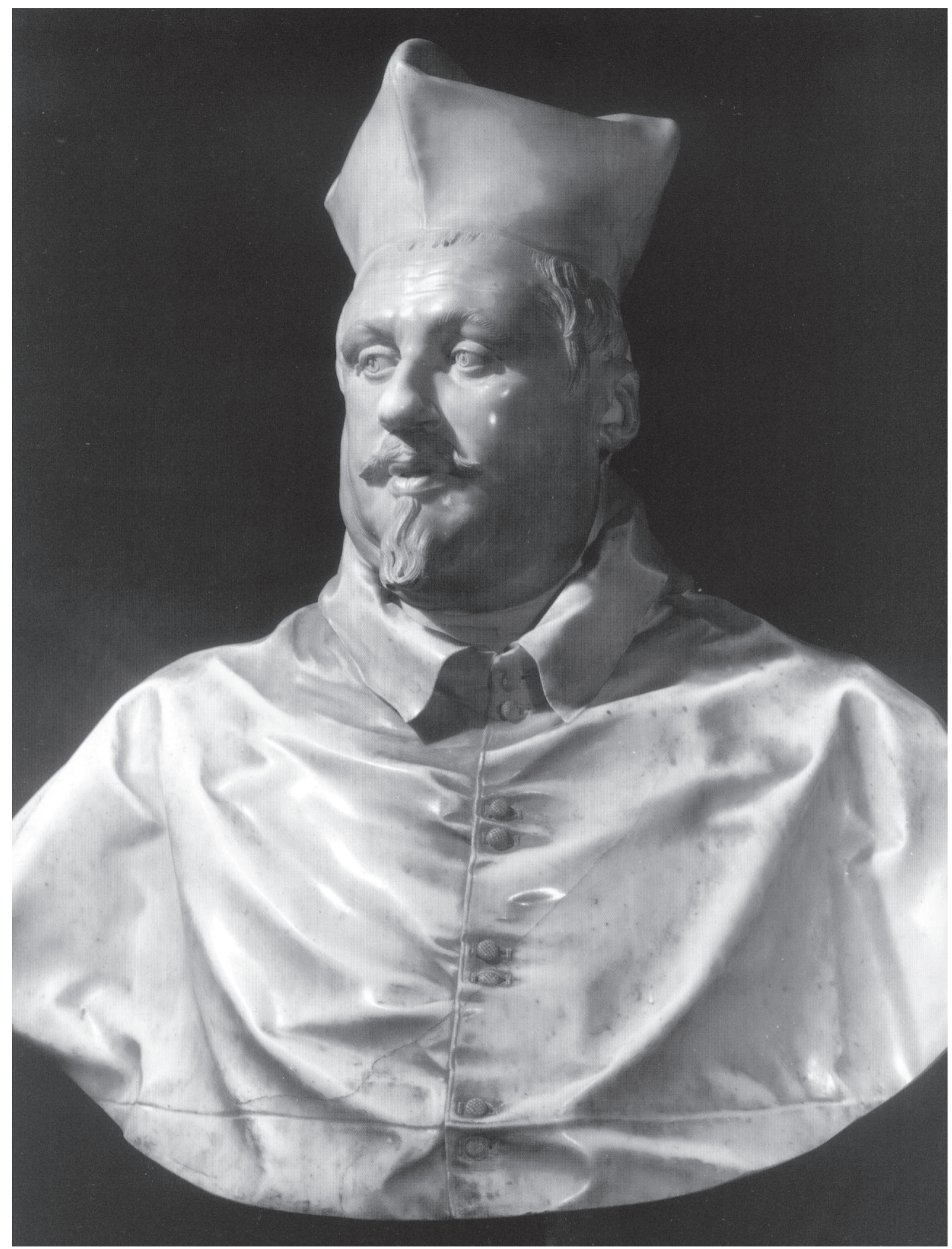

1. Giovanni Lorenzo Bernini, portret Scipiona Borghese, 1632, Rzym, Galeria Borghese. Fot. domena publiczna 


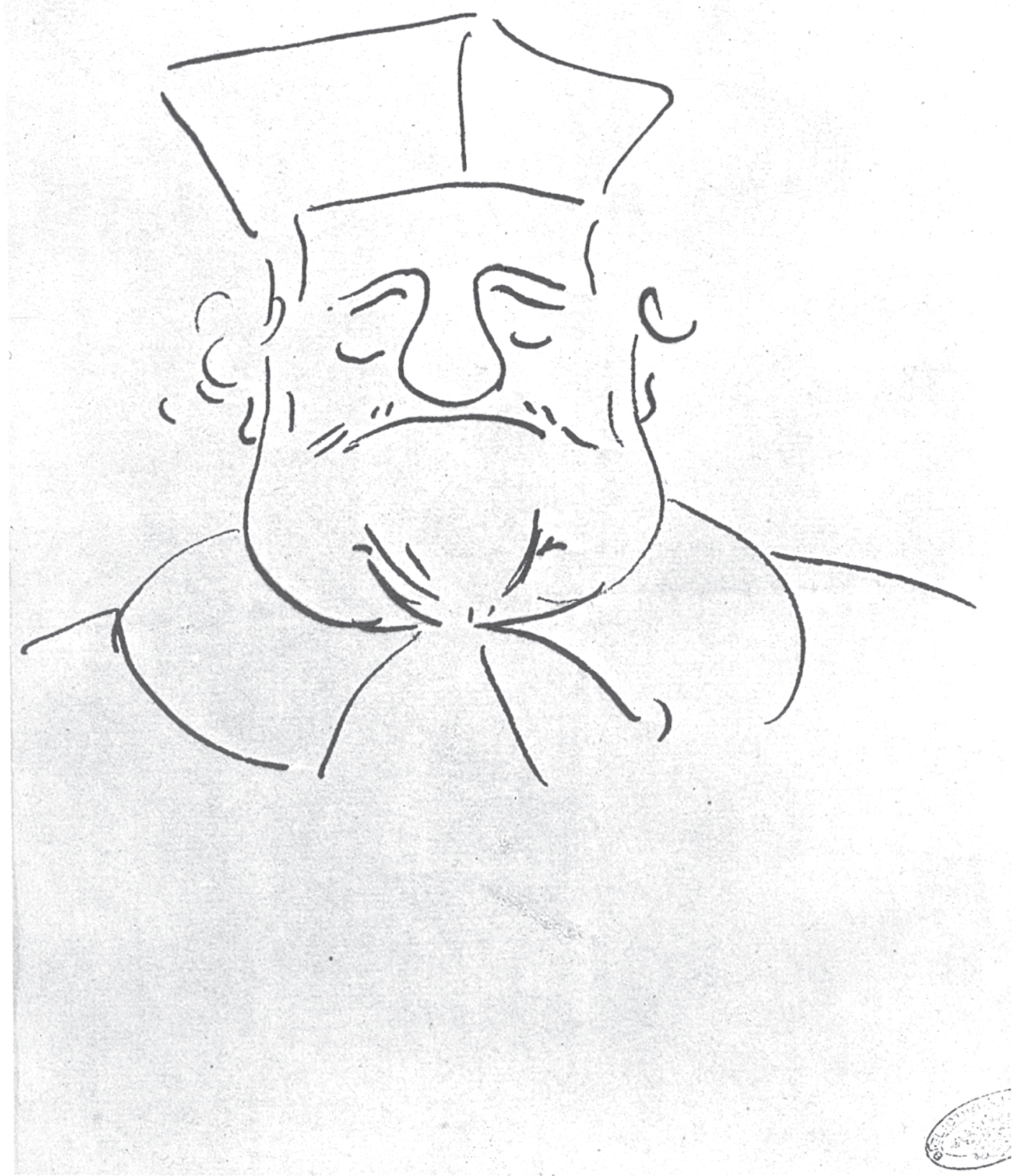

2. Giovanni Lorenzo Bernini, karykatura Scipiona Borghese, ok. 1630, Rzym, Biblioteka Watykańska. Repr. wg Bernini's drawings. Plates, red. Heinrich Brauer, Rudolf Wittkower, New York, 1969, tabl. $146 a$ 
rze, szczególnie linearnej karykaturze portretowej. Podobieństwo to zostało zauważone w poznańskiej szkole metodologicznej. Krzysztof Brzechczyn pisał: „Teoria, zdaniem Leszka Nowaka, bardziej przypomina karykaturę niż fotografię. Budowa teorii w nauce rozpoczyna się bowiem od istotnej deformacji rzeczywistości w swym pierwszym, najbardziej wyidealizowanym modelu" ${ }^{10}$. Andrzej Klawiter i Krzysztof Łastowski, opisując zbieżność teorii nauki Nowaka i karykatury, za negatywny punkt odniesienia wybrali realistyczny portret: „Teoria taka [ogólna teoria naukowa] jest systemem modeli, a zadaniem modelu podstawowego nie jest wierne odzwierciedlanie rzeczywistości, ale trafne jej deformowanie. Tak pojmowane tworzenie teorii naukowej bliższe jest szkicowaniu karykatury niż rysowaniu realistycznego portretu" 11 .

Moje zadane jest odwrotne - opisanie karykatury jako sposobu przedstawiania podobnego do idealizacyjnego postępowania w nauce. Porównując karykaturę ze ,zwyczajnym", zasadniczo realistycznym portretem, należy zwrócić uwagę na bardzo ograniczony zasób informacji, jaki daje nam upraszczająca karykatura. Szczególnie dobitnie widać to w prezentowanych wizerunkach Scipione Borghese autorstwa Gianlorenza Berniniego (il. 1-2). Przerysowanie czy uwypuklenie cech odbywa się nie tylko przez deformację przedstawianego przedmiotu, ale przede wszystkim przez pominięcie wszystkich innych aspektów przedstawianej rzeczywistości. Nie mamy do dyspozycji światłocienia, iluzji przestrzeni, koloru, ale i bez tego charakterystyka modela wydaje się przekonywająca.

Rozważania na temat ilościowych aspektów informacji w odniesieniu do komunikacji wizualnej podjął Mieczysław Porębski w rozprawie Sztuka a informacja12. O ile przeliczenie bitów, jakie zawiera tekst, nie nastręcza trudności, przełożenie dzieła plastycznego na kod dwójkowy jest dużo trudniejsze. Porębski pisał w czasie kiedy grafika komputerowa nie była codziennością (pierwsze wydanie tekstu - 1962), ale jego opis eksperymentalnego dzieła wydaje się trafny: „A pojemność kartki, na której rysujemy lub malujemy? Moc takiej kartki wydać się może nieograniczona. Czy taką kartkę możemy w ogóle uznać za zbiór wieloelementowy? Możemy, ale tylko pod warunkiem, że nie będą nas interesowały różnice dla naszego oka nieuchwytne. Przyjąwszy takie założenie, możemy spróbować nakładać na naszą kartkę rastry siatkowe różnej gęstości. Dobrawszy raster, w którym już nie rozróżniamy poszczególnych oczek, uznamy go za poszukiwaną granicę uchwytności i przyjmiemy liczbę oczek mieszczących się na naszej kartce za liczbę elementów, jaką układ taki dysponuje. Będzie ona dość wysoka, ale jednak skończona. Pozostaje wtedy do określenia repertuar tych minimalnych oczek. W wypadku najprostszym - niech będzie to rysunek tuszem - ograniczy się on do przeciwstawienia czarne-białe, co pozwoli nam potraktować nasze oczka jako układy binarne. Pojemność kartki będzie wtedy równa ilości oczek i zależna wyłącznie od jej rozmiarów. Gdy rysunek zastąpimy lawowaniem, będziemy musieli użyć zamiast skali binarnej skali bardziej zróżnicowanej, znajdując odpowiedni próg uchwytnej jeszcze różnicy walorowej. Pojemność kartki znacznie się w takim wypadku powiększy. Jeszcze większa stanie się, gdy na kartkę wprowadzimy

\footnotetext{
${ }^{10}$ Krzysztof Brzechczyn, „Między idealizacją, filozofią historii a metafizyką. Próba prezentacji i recepcji wątków badawczych w twórczości Leszka Nowaka", w: Nauki humanistyczne i społeczne wokót problemów współczesnego świa$t a$, red. Zbigniew Drozdowicz (Poznań: Wydawnictwo Naukowe Wydziału Nauk Społecznych Uniwersytetu im. Adama Mickiewicza, 2015), s. 305.

${ }^{11}$ Andrzej KLAWITER, Krzysztof ŁastowsKI, „Leszek Nowak i jego koncepcje z filozofii nauki, filozofii społecznej i metafizyki”, Studia Metodologiczne 31 (2013), s. 29.

${ }^{12}$ Mieczysław PoRĘBSKI, „Sztuka a informacja”, w: ID., Sztuka a informacja (Kraków-Wrocław: Wydawnictwo Literackie, 1986), s. 7-80.
} 
kolor, a do rachunku dodatkowe wielostopniowe skale tonów i nasycenia. Moglibyśmy się jeszcze zastanawiać, jak dalece obniża pojemność, a tym samym zuboża przekazywaną informację reprodukcja naszej doświadczalnej kartki, operująca rastrem zbyt grubym, skaląjasności uproszczoną, skalą tonów i nasycenia ograniczoną do kilku barw składowych. Dla malarza będą to wszystko rzeczy oczywiste"13. Jest to oczywiste również jeśli przyjrzymy się wielkościom plików - reprodukcji dzieł sztuki i ile potrzeba pamięci komputerowej, aby uzyskać zadowalający efekt w przypadku różnych dzieł sztuki fotografowanych i później wyświetlanych na komputerowym ekranie.

Linearna karykatura potrzebuje najmniej informacji, aby po redukującej reprodukcji w dalszym ciagu zachowywać swoją moc, co w praktyce pokazywały bardzo niskiej jakości ilustracje w prasie codziennej. Eksperymentalnym potwierdzeniem tego był stworzony w latach 80 . XX w. przez Susan E. Brennan program do rysowania karykatur, w którym wystarczało jedynie około 400 bajtów do opisania jednej twarzy (dla porównania obecnie zwykłe zdjęcie zajmuje kilka milionów bajtów pamięci) ${ }^{14}$. Zasada działania programu jest zaskakująco prosta i zaskakująco dobrze odpowiada istocie karykatury jako przesadnej charakterystyki człowieka. Na materiale wyjściowym - frontalnym zdjęciu jakiejś osoby - użytkownik programu zaznaczał punktami istotne elementy fizjonomii: obrys twarzy, kontur ust, kąciki oczu etc. Punkty te były porównywane z odpowiadającymi im punktami podobnie spreparowanej, wzorcowej twarzy. Następnie odległości pomiędzy punktami, czyli różnica pomiędzy ideałem a twarzą podlegającą karykaturze ulegała powiększaniu, które można było stopniować,, można było też zmniejszyć opisane odległości między punktami, wtedy uzyskiwano idealizowany wizerunek ${ }^{15}$. Autorka wskazała też na zasadniczą różnicę pomiędzy karykaturami tworzonymi w opisany sposób a działalnością rysownika - wybierającego arbitralnie cechy, które mają być podkreślone i poddane deformacji ${ }^{16}$.

Wybór pojedynczej cechy przedstawianego bohatera stał się istotnym elementem repertuaru politycznego karykaturzysty od przełomu XVIII i XIX po wiek XX. Jak zauważyli Ernst H. Gombrich i Ernst Kris, James Gillray stworzył dla poszczególnych osobistości europejskiego życia politycznego swoich czasów uproszczone, łatwe do zapamiętania wizerunki, oparte jednak na wybranych rzeczywistych cechach postaci ${ }^{17}$. Dzięki temu można było łatwo konstruować narracyjne obrazy, które ostatecznie wykształciły się w formułę określaną w języku angielskim mianem ,cartoon” zawierającą w sobie karykaturę i komiks we współczesnym polskim rozumieniu. Uproszczenie fizjonomii bohaterów, aby dostosować ich do założonej opowieści, można porównać do idealizacji bohaterów w akademickim obrazie historycznym. Pojawia się więc jeszcze jeden punkt zbieżny między karykaturą a idealizacją w sensie upiększenia i dostosowania do wzorca klasycznego.

Należy zadać pytanie: co w takim przypadku byłoby przeciwieństwem karykatury? Narzucająca się odpowiedź brzmi: realistyczne oddanie rzeczywistości. Problem realizmu jako

\footnotetext{
${ }^{13}$ Ibid., s. 20.

${ }^{14}$ Susan E. Brennan, „Caricature Generator: The Dynamic Exaggeration of Faces by Computer”, Leonardo 18, nr 3 (1985), s. 174.

${ }^{15}$ Ibid., s. $173-175$.

${ }^{16}$ Ibid., s. 173.

${ }^{17}$ Ernst H. Gombrich, Ernst Kris, Caricature (Harmondsworth: King Penguin, 1940), s. 19; ogólnie o prostocie karykatury oraz podobieństwie prymitywnych rysunków tworzonych w wyniku nieumiejętności i celowego uproszczenia przez świadomych rzemiosła fachowców na s. 23-24.
} 


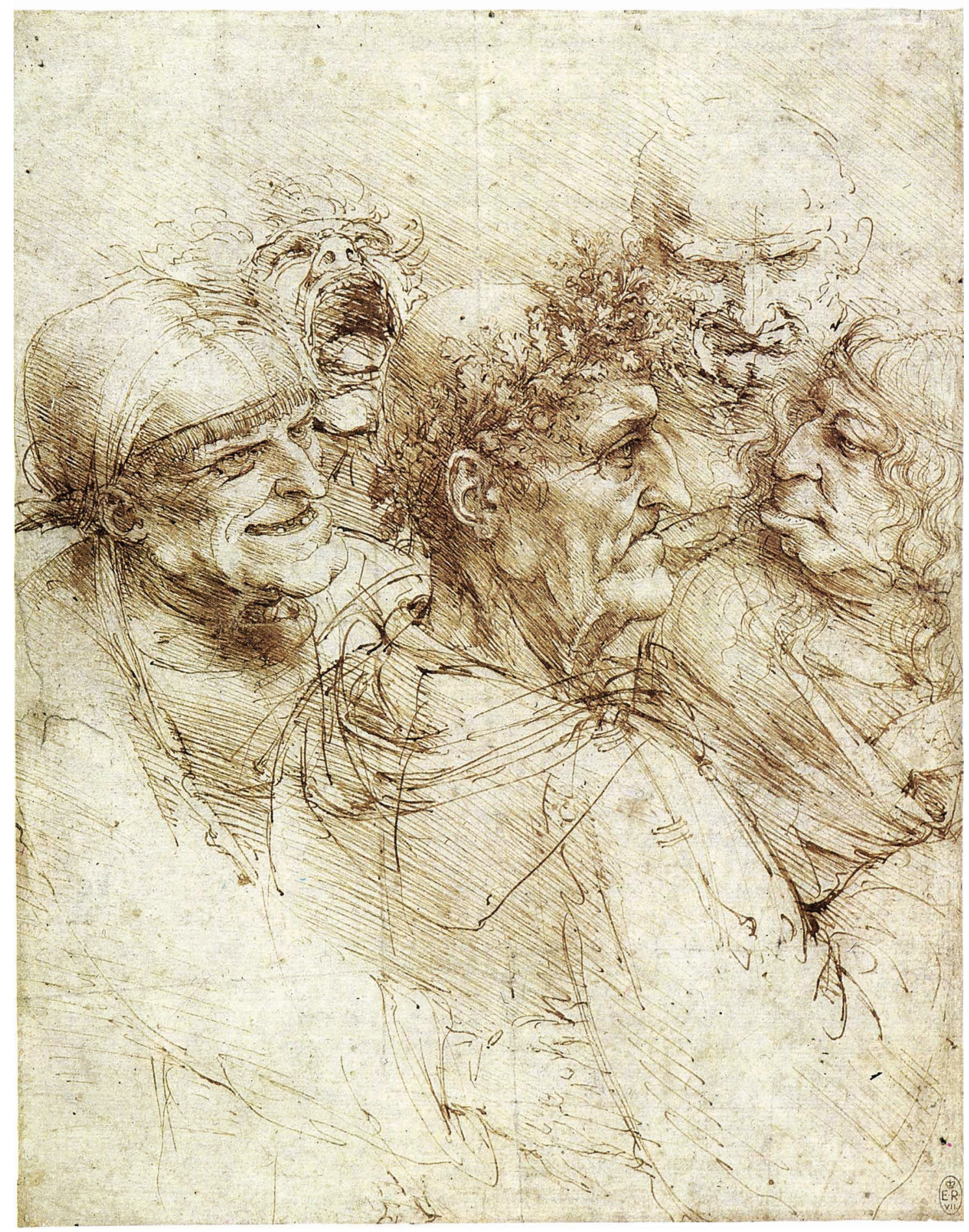

3. Leonardo da Vinci, Groteskowe głowy, ok. 1490, Royal Collection.

Repr. wg Leonardo da Vinci, katalog wystawy Hayward Gallery, London 1989, red. Martin Kemp, Jane Roberts, New Haven and London, 1989, kat. 90 
sztuki nieopartej na konwencji ,,postawił na ostrzu noża” Eugène Delacroix, jeszcze zanim XIX-wieczny realizm zaczął święcić swoje największe tryumfy. W notce z 26 kwietnia 1847 r. Delacroix odnosił się do poglądów Aleksandra Dumas'a i jego zwolenników: „Chcieliby sztuki wolnej od konwencji. Ówczesne [u Moliera i innych pisarzy XVII w.] domniemanie nieprawdopodobieństwa nie raziły nikogo; ale to, co razi w dziełach tych panów [Dumasa i innych] to mieszanina prawdy doprowadzonej do przesady której sztuka nie znosi - i uczuć, charakterów czy sytuacji fałszywych i przejaskrawionych. Czemu nie mówią, że rycina albo rysunek nic nie wyrażają, ponieważ brak im koloru? Gdyby byli rzeźbiarzami, malowaliby posagi i wprawiali je w ruch przy pomocy sprężyn, sądząc, że w ten sposób zbliżają się znacznie do prawdy"18. Według Delacroix idealizacja w sztuce jest konieczna, podobnie jak arbitralne konwencje ułatwia porozumienie między autorem a odbiorcą dzieła. Uważał jednak, że ideał może, a nawet powinien być inny niż akademicko-klasyczny ${ }^{19}$.

Realizm czy poczucie właściwego oddania rzeczywistości jest zmienne w czasie, zmieniają się oczekiwania dotyczące tego, co jest tym przezroczystym, zwykłym przedstawieniem, co upiększeniem, a co nadmierną charakterystyką, czyli karykaturą ${ }^{20}$. Realistyczny portret sytuowałby się więc pomiędzy idealizacją - upodobnieniem do powszechnego modelu ludzkiego piękna, a idealizacją w przeciwnym kierunku - wyborem i podkreśleniem jedynie najbardziej charakterystycznych cech konkretnego człowieka.

Pojęcie ideału jest jednak stosowane również w odniesieniu do zwykłych portretów. Zdaniem Johanna Caspara Lavatera, jednego z najbardziej uważnych obserwatorów ludzkich wizerunków, były one niezbędną dla niego pomocą w badaniach nad wyglądem i charakterem: „Das Porträt ist das Ideal eines gewissen Menschen; nicht das Ideal eines Menschen überhaupt" (Portret reprezentuje ideał konkretnego człowieka, a nie ideał człowieka w ogóle $)^{21}$. Ideał jest w tym rozumieniu istotą danej osoby, którą należy uchwycić odpowiednio oddając jej cechy zewnętrzne, ale to tylko środek do celu. Lavater analizował również karykatury, ale nie cenił wysoko tego sposobu wyrazu: „Aus der Carrikatur kannst du leicht auf die Wahrheit schließen. Carrikatur ist ein Vergrößerungsglas für blödere Augen" (Z karykatury można wydobyć wiele prawdy. Karykatura to szkło powiększające dla głupich oczu $)^{22}$.

\footnotetext{
${ }^{18}$ Eugène Delacroix, Dzienniki, tłum. Joanna Guze, Julia Hartwig (Wrocław: Zakład Narodowy im. Ossolińskich, 1968), t. 1, s. 134.

${ }^{19}$ Ogólnie o estetycznych poglądach Delacroix zob. Robert SHARRY, „Delacroix's Definition of Art”, Art Journal 24, nr 2 (1964-1965), s. 119-123.

${ }^{20}$ Symptomatyczne, że publikacji na temat realizmu w literaturze i sztukach plastycznych jest wielokrotnie więcej niż dotyczących idealizacji. Hasło „realizm” daje w katalogu Biblioteki Narodowej 22650 wyników, „idealizacja” 24, z czego połowa dotyczy omawianej wyżej teorii nauki; katalogi.bn.org.pl (dostęp 11 X 2019). Zmiana poczucia stosowności w realistycznym lub nieznacznie idealizowanym portretowaniu może prowadzić do całkowicie odmiennych interpretacji, wręcz uznania reprezentacyjnego portretu za karykaturę, jak to stało się z portretem rodziny króla Filipa IV Goi w opiniach francuskich krytyków 2. połowy XIX w. i późniejszych ogólnych opracowaniach historyczno-artystycznych; zob. Edward J. Olszewski, „Exorcising Goya's. The Family of Charles IV”, Artibus et Historiae 20, nr 40 (1999), s. 169-185; Alisa LuXENBERG, „Further Light on the Critical Reception of Goya's Family of Charles IV as Caricature”, Artibus et Historiae 23, nr 46 (2002), s. 179-182.

${ }^{21}$ Johann Caspar Lavater, Physiognomische Fragmente, zur Beförderung der Menschenkenntniß und Menschenliebe, (Leipzig und Winterthur: Weidmanns Erben und Reich und Heinrich Steiner und Compagnie, 1778), t. 4, s. 196. Więcej o relacji karykatury i portretu wraz z omówieniem konkretnych ilustracji książki Lavatera zob. Maciej JARZEWICZ, Sztuka a wizualizacja naukowa. Ilustracje do „Fragmentów fizjonomicznych” Johanna Caspara Lavatera (Warszawa: Neriton 2013), s. 60-61, 89-96, 101-104.

${ }^{22}$ Lavater, Physiognomische Fragmente, 1775, t. 1, s. 226.
} 
Nie zgadzając się w pełni ze stwierdzeniem, że to szkło powiększające dla głupich oczu, chciałbym podkreślić istotną rolę karykatury w docieraniu do prawdy, podobną w działaniu do uproszczenia i idealizacji w praktyce naukowej. Ryzyko błędu lub celowych nadużyć jest w karykaturze podobne do tych samych zjawisk w nauce. Nie należy mieć pretensji do karykatury czy teorii naukowej, że upraszcza, ale bez wattpienia zdarzają się błędy i celowe manipulacje. Tych ostatnich jest szczególnie dużo w karykaturze politycznej, wtedy nadużycia są maskowane konwencją karykatury, dzięki której można bronić wątpliwych rozstrzygnięć wskazując na upraszczające, nierealistyczne właściwości tego sposobu wyrazu.

Porównanie idealizacji w karykaturze i w nauce ma też inne istotne ograniczenie. Jest nim przesada, charakterystyczna dla rittrati carichi, czyli dosłownie ,,przeładowanych portretów". W karykaturze portretowej deformacja jest celowa i świadomie powiększana przez rysownika, należy to do samej istoty tej działalności artystycznej. Zniekształcenie rzeczywistości w nauce jest raczej ubocznym skutkiem idealizacji, czyli usunięcia drugorzędnych informacji. Karykaturzysta rysuje za duże albo odwrotnie za małe oczy celowo, aby podkreślić odchylenie przedstawianej osoby od idealnej normy. Inaczej w opisie naukowym. W szeroko znanym przykładzie z zakresu mechaniki klasycznej swobodnie spadająca kula leciałaby za szybko lub za daleko w porównaniu do rzeczywistych obiektów dostępnych eksperymentatorowi. To „za daleko” względem rzeczywistości jest w nauce efektem koniecznym, ale w ostatecznym rozrachunku niepożądanym. Do złagodzenia efektu przesady, jaki tworzy idealizacja, teoria naukowa dysponuje procesem konkretyzacji, kiedy opis z powrotem zbliża się do przedmiotu. W karykaturze trudno wskazać odpowiedniki procesu konkretyzacji i weryfikacji. Konkretyzacją mogłoby być uzupełnienie przez widza cech danej osoby, jeśliby znał ją z własnego doświadczenia, czy innych przekazów, o weryfikację słuszności, poza całkowicie subiektywnym, każdorazowym poczuciem trafności, jeszcze trudniej. Mimo tych ograniczeń, porównanie idealizacji w nauce i karykaturze odkrywa istotną część działania jednej i drugiej dziedziny życia, w zdecydowanie większym stopniu niż tylko metaforyczne wytłumaczenie działania teorii naukowej.

Uznanie idealizacji i uproszczenia za kluczową cechę karykatury miałoby istotne konsekwencje dla jej historii. Przede wszystkim należałoby wykluczyć z tego zbioru znaczną część dzieł uchodzących za karykatury. Podam tylko jeden przykład, groteskowe głowy Leonarda da Vinci (il. 3.) - detaliczne, opisujące każdy szczegół przedstawienia, które w dodatku nie dokonują jednoznacznej charakterystyki modela pozostając raczej na poziomie rejestracji faktów niż idealizacyjnej próby wniknięcia w istotę rzeczy. $Z$ powodu braku komizmu wątpliwości w określaniu groteskowych głów Leonarda mianem karykatury miał Charles Baudelaire: „Wszyscy artyści znają karykatury Leonarda da Vinci, prawdziwe portrety. Tym odrażającym i zimnym karykaturom nie brak okrucieństwa, ale brak im komizmu; żadnego porywu, ani cienia naturalnej swobody. Wielki artysta nie bawił się rysując; robił swoje karykatury jak uczony, geometra, profesor historii naturalnej. Nie pominął najmniejszej brodawki czy włoska. Może nie miał zamiaru robić karykatury. Szukał wokoło typów przesadnie brzydkich i kopiował je wiernie"23.

$\mathrm{Z}$ tego fragmentu możemy wyczytać również pozytywistyczno-empiryczną teorię nauki, która dominowała około połowy XIX w., a w odbiorze potocznym istnieje po dziś dzień. W takim rozumieniu porównując pracę Leonarda do badań naukowych Baudelaire

\footnotetext{
${ }^{23}$ Charles Baudelaire, „O kilku karykaturzystach obcych”, w: ID., Rozmaitości estetyczne, thum. Joanna Guze, (Gdańsk: Słowo/Obraz Terytoria, 2000), s. 193.
} 
ma oczywiście racje. Gdyby zastosować jednak idealizacyjną teorię nauki Leszka Nowaka, należałoby uznać Leonarda za Arystotelesa, starożytnego filozofa opierającego się wyłącznie na empirii i zdrowym rozsądku. Galileuszem w karykaturze byłby więc Bernini - idealizujący, upraszczający i zmierzający do istoty rzeczy z pominięciem jakichkolwiek zbędnych szczegółów. 


\section{Idealization in Caricature. Caricature as Idealization. A Sketch.}

Idealization in fine arts and literature consists first of all in showing a section of reality in a way approximating it to the model of beauty and good. Suchperceived idealization is characteristic of classicizing trends in art, and quite overtly contradictory to the principles that rule caricature which, in turn, magnifies qualities of an object in order to distance it from the ideal, and ridicule it.

Another concept of idealization operates as science philosophy, particularly in that formulated by Leszek Nowak. Idealization is an inseparable element of scientific investigation: it consists in analysing only the most essential attributes of an object, neglecting all the others. The most frequently quoted example is the law of free fall in classical mechanics which neglects the air drag forces. In the concept formulated by Nowak and his school, the theory does not need to be literary true, so it is falsified, however what is compared with the reality is the concretization effect, namely the taking into account of the earlier neglected attributes and circumstances. Scholars from Nowak's school observed the similarity between drawing a caricature and creating idealizing science theories, however they did not expand on this thought.

On the other hand, a similarity between the work of a caricaturist and an idealizing artist appeared from the very beginning of the existence of the term caricature (Giovanii Antonio Massani, Le Arti di Bologna, 1646, featuring reproductions of Annibale Carracci's drawings). According to the paper's Author, an idealizing artist (the example of Raphael) does not render the reality directly, however a caricaturists acts similarly, paradoxically achieving the beauty of the deformation (bellezza della deformità). An essential quality of a caricature is simplicity in terms of scarcity of information allowing to recreate a simple drawing, such as G.L.Bernini's caricature of Scipione Borghese versus the sculptural portrait of the same individual. In the opinion of E. H. Gombrich and Ernst Kris, simplification of the appearance and creation of an easily-recognizable figure applied in cartoons became the breakthrough point for the social functioning of caricature at the turn of the $19^{\text {th }}$ century.

However, there is one essential difference between the idealization in science theory and caricature: the exaggeration effect resulting from idealization is in science accidental, and should be corrected in the concretization. Contrariwise, in caricature exaggeration belongs to the very nature of this branch of art. Nevertheless, considering idealization as the key feature of caricature allows to better understand the phenomenon, and better outline its chronology. 


\section{Bibliografia:}

Brennan, Susan E. "Caricature Generator: The Dynamic Exaggeration of Faces by Computer." Leonardo 18, nr 3 (1985): 170-78.

Brzechczyn, Krzysztof. "Między idealizacją, filozofią historii a metafizyką. Próba prezentacji i recepcji wątków badawczych w twórczości Leszka Nowaka". W Nauki humanistyczne i społeczne wokót problemów wspótczesnego świata, red. Zbigniew Drozdowicz, (Poznań: Wydawnictwo Naukowe Wydziału Nauk Społecznych Uniwersytetu im. Adama Mickiewicza, 2015): 303-318.

Hofmann, Werner. Die Karikatur von Leonardo bis Picasso. Wien: Philo Fine Arts, 1956.

Jarzewicz, Maciej. Sztuka a wizualizacja naukowa. Ilustracje do „Fragmentów fizjonomicznych” Johanna Caspara Lavatera. Warszawa: Neriton 2013.

Klawiter, Andrzej, Łastowski Krzysztof. „Leszek Nowak i jego koncepcje z filozofii nauki, filozofii społecznej i metafizyki”, Studia Metodologiczne 31 (2013): 25-42.

Kozakiewicz, Stefan, red. Stownik terminologiczny sztuk pięknych. Warszawa: PWN, 1969.

Luxenberg, Alisa. „Further Light on the Critical Reception of Goya's 'Family of Charles IV' as Caricature." Artibus et Historiae 23, nr 46 (2002): 179-82.

McTighe, Sheila. „Perfect Deformity, Ideal Beauty, and the „Imaginaire” of Work: The Reception of Annibale Carracci's 'Arti Di Bologna' in 1646.” Oxford Art Journal 16, nr 1 (1993): 75-91.

Nowak, Leszek. Wstep do idealizacyjnej teorii nauki. Warszawa: PWN, 1977.

Olszewski, Edward J. „Exorcising Goya's 'The Family of Charles IV'.” Artibus et Historiae 20, nr 40 (1999): 169-85.

Porębski, Mieczysław. „Sztuka a informacja”. W id., Sztuka a informacja, 7-80. Kraków-Wrocław: Wydawnictwo Literackie, 1986.

Sharry, Robert. „Delacroix’s Definition of Art.” Art Journal 24, nr 2 (1964): 119-23.

Sławiński, Janusz, red. Słownik terminów literackich, Wrocław: Zakład Narodowy im. Ossolińskich, 1998. 
